The territorial economic impact of entrepreneurial youthfulness ${ }^{1}$

\author{
Esteban Lafuente \\ Department of Management, Universitat Politècnica de Catalunya (Barcelona Tech), \\ Barcelona, Spain
}

Eduardo Gómez-Araujo

School of Business, Universidad del Norte, Colombia

\title{
Main message:
}

Entrepreneurship and youth population interact to enhance economic performance, and actions oriented to bring down social barriers linked to the fear to entrepreneurial failure are as important as policies focused on access to finance or human capital formation

\section{Key points:}

Entrepreneurship generates opportunities for professional development, social and economic integration, the maintenance of the rural population and the attraction of new residents to these territories

Young entrepreneurs face more than financial constraints, as local economic conditions and their risk aversion are important barriers to engage in entrepreneurial activities To achieve greater rates of entrepreneurship amongst rural youths, policy should mould the value system of the community in general, and not exclusively that of young adults

\section{Please cite as:}

Lafuente, E., Gómez-Araujo, E. (2016). The Territorial Economic Impact of Entrepreneurial Youthfulness. Strategic Change, 25 (2), 187-204.

\footnotetext{
${ }^{1}$ JEL classification codes: J58, L26, L53,
} 


\section{Introduction}

Entrepreneurship is increasingly recognized as a critical ingredient for economic growth, employment generation, innovation and socio-economic development (OECD, 2003; Acs and Amoros, 2008; Wyrwich, 2012). Yet, do young entrepreneurs have a relatively greater impact on territorial economic performance? According to the demographic perspective, young people promote the revitalization of the local community (OECD, 2003); therefore, without renewal of population a territory cannot remain viable or maintain its social and economic functions in the long term (Muilu and Rusanen, 2003). From the economic perspective, young individuals allow the renewal of the labor force (ILO 2010). Also, they can potentially become decisive factors for territorial development when their human capital is optimized through entrepreneurship (Xheneti, 2006; Bönte et al., 2009; European Commission, 2009; Hofer and Delaney, 2010; Liddle, 2011).

There are empirical evidence of positive relationship between youth entrepreneurship and territorial economic performance (Verheul and Van Stel, 2007). According to White and Kenyon (2000) young entrepreneurs are innovating in the organization of work, the generation and transfer of technology and new perspectives to the market. In certain circumstances, young entrepreneurs are particularly responsive to new economic opportunities and trends (OECD, 2001). One of the biggest competitive advantages that young people have in the knowledge-based economy is precisely their willingness to innovate (Lyngdoh, 2005). Similarly, new communication technologies are indispensable tools for competitiveness, and youths often have a better grasp of these than their elders. A new culture of work is emerging, and young entrepreneurs have the capacity to be leaders in this new context (OECD, 2001).

From an academic perspective, most of the focus on the determinants of territorial development has acknowledged that a territory's entrepreneurial activity contributes significantly to territorial economic performance; where the active participation of youths within the economy is found to play an especially important role (Naudé et al., 2008). However, there is a dearth of comparative research analyzing the economic contribution of young entrepreneurs against those of their older counterparts. Little is known about the potential differences across regions of the contributions of youth entrepreneurial activity for economic development. This is particularly striking 
given the policy relevance that youths are gaining in Europe in the context of the current economic downturn (European Commission, 2009, 2012). Policy makers also highlight the relevance of specific components linked to the territory's entrepreneurial climate in fostering entrepreneurship (European Commission, 2004). Yet, there is a lack of research from a longitudinal perspective that simultaneously captures the differentiated effect that certain elements of the territory's entrepreneurial climate have on entrepreneurial activity of youths and non-youths, and the effect that this entrepreneurial activity has on territorial economic performance.

Therefore, we focus on young people, and the research objective of this study is to determine whether a territory's youth entrepreneurship has a greater impact on its economic performance than that of older entrepreneurs at territorial level in Spain. The study also strives to identify the dynamics at work behind the expected relationship between youth entrepreneurship and territorial economic performance.

The empirical application considers a unique dataset of Spanish individuals for the period 2004-2008. The analysis of youth entrepreneurship within Spain is particularly attractive since Spain is one of the OECD countries with the highest proportion of business start-ups by young people (Coduras et al., 2012). Also, and putting the current economic difficulties aside, the gross domestic product (GDP) of the Spanish economy between 1980 and 2008 grew consistently above that of Europe (OCDE, 2012). Finally, previous evidence points out that Spain's regions show important differences in their entrepreneurial activity, and this variation can be partly explained by the different propensity towards an entrepreneurial career across territories (Lafuente et al., 2007). This further supports the joint analysis of the relationships between elements linked to the entrepreneurial climate, youths' entrepreneurial activity and economic performance.

The reminder of the study is structured as follows. Section two presents the theoretical framework and the development of the hypotheses. Section three shows the data and methodology. Section four contains a discussion of the main results and section five comments on the conclusions and implications. 


\section{Theoretical Framework and Hypotheses}

\section{Youth population in the territories}

What can happen to a territory that runs out of young people? Without a proper rejuvenation of a territory's population, its economy cannot remain viable or maintain their long-run socio-economic functions (European Commission, 2009; Headey and Hodge, 2009). Territories without youths will not endogenously renew the labor force and without immigration, economic activity will diminish (ILO, 2010).

Thus, the proportion of young people is crucial to maintain a stable economy (Van Groezen and Meijdam, 2004). In a population with few youth, the ratio of retired people who generate dissavings to working people who save for their retirement will be high, and hence the aggregate saving rate will be reduced (Futucami and Nakajima, 2001). Then, having a young population structure in an economy not only allows a constant offer of human capital for the job market; but also for the proper functioning of the health, fiscal and pension systems (Werner Sinn, 1999; Headey and Hodge, 2009).

Youth are not only important to support the economy but also to stimulate its growth. Liddle (2011) explains that economies grow in regions with a greater population of youth, who are well educated and who have opportunities to develop their talents. Verheul and Van Stel (2007) contribute to this perspective, arguing that in developed regions young individuals not only optimize human capital by the way of employment, but also by entrepreneurship.

In the context of EU and OECD countries the proportion of youth is very important to territorial development (Fougère and Mérette, 1999; OECD, 2001; Bönte et $a l ., 2009)$. Firstly, because within a territory a large agglomeration of youth can generate a dynamic population mass that claim different sorts of essential services and products. Young people also represent a local market for leisure activities that might otherwise be unavailable; cinemas, bars, restaurants and other proximity services that can enhance the quality of life of the entire local population, making a given place more attractive for residents of all ages (OECD, 2012). Secondly, and according to the OECD, attracting and retaining young talent in the region is not only a means of maintaining a demographic balance and avoiding population ageing, it is also the way to maintain a healthy and dynamic labor supply.

Some interesting cases where young people have played a key role in economic performance can be found in regions of countries like Canada (OECD 2010), Germany, 
Sweden and Denmark (Naudé et al., 2008). These countries had specific territories with a lack of youth and a critically aging population. Many of these areas were able to turn their economy around and generate economic performance once there governments carried out policies to attract and maintained young people in the territory.

Eurostat (2009) has argued that if Europe wants to continue supporting its economic recuperation, it will need to increase the European youth population over the next decades. According to this organization youth and their elders will face two demographic challenges in the near future: the impending decline and aging of the European population. From this it can be hypothesized that:

H1. Territories with a greater proportion of youths have higher levels of GDP per capita.

\section{Entrepreneurial activity in the territories}

As mentioned youth play a key role within territorial economic performance. Young individuals can contribute to the economy in two ways: first, through the labor market as productive wage-earners; or alternatively, through entrepreneurial activity as promoters of new business ventures. Some scholars maintain that entrepreneurial activity is a determinant of economic performance (Wennekers and Thurik, 1999; Meccheri and Pelloni, 2006; Audretsch and Keilbach, 2007; Fritsch and Mueller, 2008; Naudé et al., 2008; Audretsch et al., 2012). What are the reasons for this? From an academic perspective, there are three links between entrepreneurship and economic development: first, innovation; second, firm start-ups and job creation; and third, competitiveness (Karlsson et al., 2004). Some studies suggest that the function of entrepreneurship as the driving force of economic development is due to its role as the conveyor of innovation to the markets (Audretsch and Thurik, 2001; Carree and Thurik, 2002; Acs and Amoros, 2008). According to Karlsson, Friis and Paulsson (2004), empirical studies show that increased competition has been found to stimulate greater employment as well as enhance growth in total factor productivity. Similarly, small firms produce a large share of the total number of innovations (Acs, 1996).

This impact of entrepreneurship occurs at different territorial levels (countries, regions, cities and rural and urban areas), and scholars have found that the correlation between business start-up and economic performance varies widely across territories 
(Audretsch and Thurik, 2001; Freytag and Thurik, 2007; Fritsch, 2008; Bosma et al., 2010). According to Malecki (1993) the studies of entrepreneurship and new firm formation have demonstrated that not all places are alike in their potential to generate economic growth. This author suggests that these variations are possibly explained from three dimensions of territorial environment such as industrial structure, organizational structure and the entrepreneurial climate or milieu. There is a complex relationship between social-economic structure, culture and entrepreneurship (Davidsson, 1995).

On the other hand, scholars have also argued that besides the important cultural characteristics, diverging demographic and entrepreneurship levels also significantly impact economic performance (Freytag and Thurik, 2007). Previous studies mainly analyzed the impact of new business formation on territorial development or countries, using correlations or regressions analysis to assess the relationship between new business formation and economic development (Van Stel et al., 2005). These same authors confirmed a positive effect of entrepreneurial activity on the GDP across of sample of 36 countries. Grilo and Thurik (2006) found similar evidences in a sample of European countries and the USA. They indicated that the differences in the economic growth levels of these countries are related to distinct levels of entrepreneurial activity.

These characteristics differ not only across countries, but also within countries across regions (Audretsch et al., 2012). Thus, territorial economic prosperity is strongly associated with the vitality of firm formation rates (Malecki, 1993). In the case of Germany the different phases of the effects of new business formation on territorial development are relatively pronounced in agglomerations as well as in regions with a high-level of labor productivity. In low productivity regions, the overall employment effect of new business formation rates is negative (Fritsch and Mueller, 2008).

Similar evidence has been found in regions outside Europe and the USA. Such is the case of India, where Göel et al. (2006) found that regions with more entrepreneurial activity have greater GDP. In this country, for example, the western region had the highest number of registered companies in India and the eastern region had the least number of businesses. According to these authors, it is likely that regions having greater entrepreneurial development activity would have more success stories, have presence of informal networks to support entrepreneurship, exhibit more resilience in case of failure, benefit from informal learning from social channels of communication, and encourage entrepreneurial activity. All these together give rise to a positive spiral that 
promoting entrepreneurial activity. On the other hand, in less developed regions, there is lack of evidence of entrepreneurial success and therefore fewer examples from which people can learn about entrepreneurship. As a result, a negative spiral may lead to apprehensive attitudes towards entrepreneurs and entrepreneurial activity (Göel et al., 2006). Consequently, for all the above arguments, we propose the following hypothesis:

\section{H2. A territory with higher entrepreneurial activity will have higher GDP per capita.}

\section{The influence of young entrepreneurs at territorial level}

As we have mentioned in the last item, economic performance is in part an outcome of entrepreneurship in a specific territory. This entrepreneurship is in itself the result of the efforts carried out by individual entrepreneurs active in this territory. When establishing a link between entrepreneurship and territory, one must consider that a territory possesses assets (factors), know-how and social capital. Entrepreneurs are the ones that in large part configure all these inputs into new products or services through new ventures (Benneworth, 2004). Audretsch et al. (2012) suggest that the fortunes of regions and entrepreneurs are intertwined; territorial endowments provide opportunity and resources for entrepreneurs, while entrepreneurs simultaneously shape the local environment. That is to say, entrepreneurs may impact territorial economic growth through innovation and new firm formation (Acs et al, 2004).

Studies into the propensity of individuals towards an entrepreneurial career at the territorial level demonstrate that one of the most determinant factors is the age of the person (Bönte et al., 2009). These authors find, in the case of German regions, a relationship between age structure and start-up activity in the regions. Similar studies in other regions have found that the individual age effect suggests decreasing entrepreneurial activity in an aging society (Katz, 1994; Vaillant and Lafuente, 2007). Precisely, a common empirical finding by scholars in this area has been that young adults are more likely to be entrepreneurs than non-youths (Honjo, 2004; Levesque and Minniti, 2006). There are several reasons that have been advance to explain this correlation. On the one hand, the learning and adaptation capacity of youths often outpaces that of their older counterparts, allowing them to act more swiftly upon identified opportunities (Honjo, 2004). Furthermore, today's youths generally have greater affinities with some abilities and skills that have become highly prized within 
the current knowledge-based economy, allowing them to better take advantage of certain business opportunities (Xheneti, 2006).

Moreover, as individuals get older they find the idea of starting a new business less desirable because their risk aversion increases with the years (Levesque and Minniti, 2006), while youths have a lower opportunity costs when it comes to creating a business (Amit et al., 1995). For instance, if a young person fails in her attempt to be an entrepreneur, she is young enough to easily return to the labor market, as opposed to older people, who find this more difficult (Vaillant et al., 2012). On the other hand, there is evidence in the context of developed countries that the contribution of young entrepreneurs to territorial economic performance is higher than older entrepreneurs (Verheul and Van Stel, 2007). Within a knowledge-based economy context, the attitudes and skills of youth are key factors for creating and generating new products, process, services and technology in general (White and Kenyon, 2000; Lyngdoh, 2005). Young persons have a natural disposition for innovation and change, which they are capitalizing in part through entrepreneurial activity (European Commission, 2009).

Finally, studies have found that in developed economies youths are often attracted towards entrepreneurship as a way to develop their talent, get higher incomes and greater social status (Chigunta, 2002). This is partly because entrepreneurship is seen as an outlet for the talents of many highly educated young people in areas such as information technology, biotechnology and other modern industries (Xheneti, 2006). Thus, businesses created by youths tend to have more affinity with the industrial dynamic that the knowledge-based economy needs. Also, their businesses are more oriented to international or digital markets than businesses created by non-young entrepreneurs (Honjo, 2004; Xheneti, 2006). In contrast, non-young entrepreneurs are more risk averse and conservative when leading their own businesses (OECD, 2001). Therefore, youth entrepreneurship in developed economies generates a strong added value that positively impacts economic performance (European Commission, 2009; Hofer and Delaney, 2010). Given these arguments, we hypothesize:

H3. As compared to that of non-youths, a territory's youth entrepreneurial activity level has a greater impact on GDP per capita. 


\section{Methodology}

\section{Data and definition of variables}

The data used to carry out this research come from two main sources. First, we collected information about territorial demographics and economic conditions from the Spanish national statistics institute (Instituto Nacional de Estadística -INE-) for the period 20042008. Second, regarding the variables related to territorial entrepreneurial activity, these come from the adult population survey (APS) of the Spanish Global Entrepreneurship Monitor (GEM) for the same period (2004-2008). The GEM project began in 1998 as an international entrepreneurship observatory, and nowadays more than 70 countries analyze the phenomenon of entrepreneurship using this methodology (Xavier et al. 2013). Furthermore, the information generated by the GEM has been used by a large number of researchers to study entrepreneurship and its determinants (Wagner, 2004; Wennekers et al., 2005; Van Stel et al., 2005; Vaillant and Lafuente, 2007; Grilo and Thurik, 2006; Driga et al., 2009; Bosma et al., 2010). A more detailed description of the GEM methodology is presented in Reynolds et al. (2005). Information from the GEM project is generated at the individual level, and for the purposes of this study data were aggregated at the territorial level.

In this study, the unit of analysis is the territory (province) at the NUTS-3 level. The period of time that this study covers is 5 years (2004-2008). Besides data availability constraints, the reason for this period is because it comes prior to the severe economic downfall that Spain has suffered since 2009.

Analyzing the contribution of youth, entrepreneurial activity and young entrepreneurs to the economic development at the territorial level in Spain, the territories that we have chosen to study are the Spanish provinces. The current political division of the Spanish territory is based on 17 regions at the NUTS-2 level and these are divided in 52 provinces at the NUTS-3 level (Figure 1). The Spanish province has been selected as unit of analysis for this research in order to present a more detailed territorial study of Spanish entrepreneurial activity than the territorial analysis adopted in most existing research. Table 1 presents the descriptive statistics of the total entrepreneurial activity as well as that of young entrepreneurs, not-young entrepreneurs and GDP per capita of the provinces from 2004 until 2008.

The first dependent variable used in this study is entrepreneurial activity. This factor has been proposed in several studies examining territorial development 
(Audretsch and Thurik, 2001; Van Stel et al., 2005; Freytag and Thurik, 2007; Fritsch and Mueller, 2008; Audretsch et al., 2012). For the purposes of this study, aggregated data from the GEM allows creating a variable that measures the proportion of the adult population that has created a business in the year prior to the APS survey.

--- Insert Figure 1 about here ---

With respect to the definition of young people, the criterion used in this research is age based. According to several international organizations, such as the OECD (2001), the United Nations (UN, 2005), the International Labor Organization (ILO 2010) and the World Bank (2011), there is consensus when it comes to considering young people to be all people that are aged between 15 and 24 years. Meanwhile, the European Union and specifically the Government of Spain (INJUVE 2011) share the criterion that young people are those aged between 15 and 29 years. In relation to business start-up, many academics have precisely characterized young entrepreneurs as those individuals that have created or want to create a business and are aged between 18 and 29 years (Blanchflower and Meyer, 1994; Schiller and Crewson, 1997; Walstad and Kourilsk, 1998; Honjo, 2004; Levesque and Minnitti, 2006; Rojas and Siga, 2009; Thomas, 2009). Thus, for ensuring academic continuity and scientific rigor, this research adopts this criterion in order to classify a person as young.

--- Insert Table 1 about here ---

For the young and non-young sub-samples, the entrepreneurship rate refers to the proportion of the adult population involved in entrepreneurial activities. As indicated above, individuals are deemed young if they are aged between 18 and 29 years old, whereas individuals older than 29 years old are considered non-young. From the descriptive in Table 1 it can be observed that during the analyzed period non-young individuals show a slightly higher rate of entrepreneurial activity $(2.41 \%)$, compared to that of young people $(2.25 \%)$.

The second dependent variable used in this study is territorial economic performance, measured as GDP per capita. This variable is expressed in Euro at 2008 market prices. GDP has previously been used in many studies related with 
entrepreneurship and territorial economic development, in particular those by De Jorge Moreno et al. (2007), Acs and Amoros (2008), Fritsch and Mueller (2008), Naudé et al. (2008), Bönte et al. (2009), and Audretsch (2009). From Table 1 we observe that the GDP per capita in Spain grew each year between 2004 and 2008; the largest increases have been between 2004 and 2005 (2.36\%) and 2005 and 2006 (4.07\%).

In addition, we introduce five demographic control variables and three territorial factors related to the entrepreneurial climate. The first control variable of interest relates with population density, which has previously been used in studies of entrepreneurship and territorial development (Fritsch and Mueller, 2008; Bönte et al., 2009; Liddle, 2011). This variable is expressed as the number of inhabitants per square kilometer. According to Table 2, the Spanish population density averaged 286 inhabitants per square kilometer between 2004 and 2008.

--- Insert Table 2 about here ---

Secondly, we introduce unemployment. This variable has often been used in entrepreneurial and territorial development research (De Jorge Moreno et al., 2007; Naudé et al., 2008). This factor is measured as the rate of unemployed to active population in each province per year. This rate in Spain during the study period has been of $10 \%$ (Table 2). The third control variable is related to educational attainment, and it measures the proportion of individuals with university studies (Krueger, 1993; Naudé et al., 2008). Another variable considered in this research is rurality. This factor has been used previously to study entrepreneurship at a territorial level (Lafuente et al., 2007; Akgün et al., 2010). The method adopted to differentiate urban areas from rural ones in this study is based on the criterion proposed by the Spanish law of Sustainable Rural Development (Real Decreto 752/2010 of the Government of Spain: BOE, 2010). The said criterion indicates for each region a list of municipalities classified as rural. In this study rurality is the proportion of population living in rural areas. This proportion was of 40\% in Spain between 2004 and 2008. The last demographic variable in Table 2 is the proportion of young persons in the total population per province. This variable has been used by scholars as an explanatory factor when it comes to analyzing territorial development (Göel et al., 2006; Liddle, 2011). This variable is expressed in percentage 
of population. In the final sample, the provinces in Spain averaged $20 \%$ of young population between 2004 and 2008 (Table 2).

As for the variables related to the entrepreneurial climate, individual data available from the Spanish GEM were aggregated at the territorial level for analytical purposes. The first variable relates to the self-confidence in entrepreneurial skills (Lafuente et al., 2007; McGee et al., 2009). This variable captures the proportion of individuals at the territorial level that has confidence in their entrepreneurial skills. In the final sample, an average of $45 \%$ of the adult population perceived that they had sufficient entrepreneurial skills to successfully start and manage their own business (Table 2). The entrepreneurial role model is another control factor proposed in several studies of business start-ups. It has been used by many academics as a control factor when it comes to analyzing business start-ups (Krueger and Brazeal, 1994; Walstad and Kourilsky, 1998; Gibson, 2004; Lafuente et al., 2007; Vaillant and Lafuente, 2007; Lucas et al., 2009). This variable accounts for the proportion of the territorial population that personally knows an entrepreneur who has created a business over the last two years. In Table 2 it can be seen that individuals with role models represent an average of $32 \%$ of the sample. Finally, the third control variable associated with local social traits used in this paper is the social fear of failure (Landier, 2004; Wagner, 2007; Lafuente et al., 2007; Vaillant and Lafuente, 2007). For the purposes of this study, this variable is measured as the proportion of the population that states that the social fear of failure is an impediment to creating a business, and zero otherwise. People with fear of failure in this sample represent an average of $49 \%$ of the adult population (Table 2).

Econometric strategy: Modeling the relationship between entrepreneurship and territorial economic performance

The correct analysis of the impact that youth entrepreneurship has on territorial economic performance starts by acknowledging entrepreneurship as an endogenous process where different territorial and socio-cultural factors affect entrepreneurial activity rates (see e.g., Wagner and Sternberg, 2004; Lafuente et al., 2007; Bönte et al., 2009). As a result, in a first step data available from the Spanish national statistics institute and the GEM project are aggregated at the territorial level allowing the estimation of the following equation: 
Entrepreneurship $_{i t}=\beta_{0}+\beta_{1}$ Population density $_{i t}+\beta_{2}$ Unemployment $_{i t}$

$$
\begin{aligned}
& +\beta_{3} \text { Education }_{i t}+\beta_{4} \text { Rurality }_{i t}+\beta_{5} \text { Proportion of youths }_{i t} \\
& +\beta_{6} \text { Social traits }_{i t}+\beta_{7} \text { Territory }_{i t}+\beta_{8} \text { Time }_{t}+v_{i t}
\end{aligned}
$$

In equation (1) entrepreneurship is the rate of entrepreneurial activity in region $i$ at time $t$, and $v_{i t}$ is the normally distributed error term. Social-traits refer to the aforementioned variables related to the entrepreneurial climate at the territorial level, i.e., the proportion of the population that has sufficient entrepreneurial skills to successfully start and manage a business, the proportion of the population that personally knows a recent entrepreneur, and the proportion of the population that states that the social fear of failure is an impediment to start a business.

In a second step, we consider the GDP per capita as the dependent variable, and in this case entrepreneurship enters into the model as the key explanatory variable. The second model specification has the following form:

$$
\begin{aligned}
\text { GDP/capita }_{i t} & =\beta_{0}+\beta_{1} \text { Population density }_{i t}+\beta_{2} \text { Unemployment }_{i t} \\
& +\beta_{3} \text { Education }_{i t}+\beta_{4} \text { Rurality }_{i t}+\beta_{5} \text { Proportion of youths }_{i t} \\
& +\beta_{6} \text { Entrepreneurship }_{i t}+\beta_{7} \text { Territory }_{i t}+\beta_{8} \text { Time }_{t}+\varepsilon_{i t}
\end{aligned}
$$

As previously indicated, entrepreneurship is an endogenous process linked to territorial and cultural factors. Therefore, a conventional analysis using a random-effects or a fixed-effects model would potentially yield biased estimates of the effect that entrepreneurial activity has on territorial economic performance. As a result, to examine the entrepreneurship-economic performance relationship presented in equation (2) we should take into account the endogenous nature of entrepreneurship. This is the fundamental cornerstone of our modeling strategy. To correctly introduce the entrepreneurship equation into equation (2) a system of simultaneous equations is required. In this paper, we choose the simultaneous equation model using three-stage least squares method as econometric tool (Wooldridge, 2002).

This technique makes use of instrumental variables to produce consistent estimates through GLS that account for the correlation in the error terms across equations. The method has three stages. The first stage generates instrumental values for the endogenous variables of the model, in our case entrepreneurial activity and GDP per head. The instrumented values are the predicted values produced by the regression of 
each endogenous variable on all exogenous variables in the system. Stage 2 generates a consistent estimate of the covariance matrix of the equation disturbances. Finally, and using the covariance matrix obtained from stage 2, stage 3 performs a GLS regression where the instrumented values replace the endogenous variables in the model (Wooldridge, 2002).

In equation (2) we estimate two model specifications to differentiate the effect of the overall entrepreneurial activity on the GDP per capita from the specific effect that young and non-young entrepreneurship has on economic performance. Through this system of equations we can test if, after controlling for the direct effects of variables related to demographics and entrepreneurial climate, entrepreneurial activities positively affect the economic performance of territories.

\section{Empirical findings}

The results of the two simultaneous equation models carried out in order to test the proposed hypotheses are summarized in Table 3. Keeping in mind that the unit of analysis in the model is the provincial territory, results indicate which factors, from the independent variables analyzed, contribute to having greater territorial entrepreneurial activity levels (equation (1)). At the same time, the results of the simultaneous equation give us indications of how the variables analyzed contribute to a higher GDP per capita at the territorial level (equation (2)). Whereas the first model observes the entrepreneurial activity of the general adult population, the second model analyses the entrepreneurial activity of youth and non-youths separately.

The first hypothesis $\mathbf{H 1}$ of the study states that territories with a greater proportion of youths have higher GDPs per capita. As we can see from the results of the models, the proportion of young adults has no significant influence on the GDP per capita levels of a territory, nor does it have any statistically significant indirect impact on GDP per capita through its influence over the entrepreneurial activity levels of a territory. Hypothesis $\mathbf{H 1}$ is therefore not supported by the results of the study.

For there to be any indirect influence of the independent variables on GDP per capita through their impact upon the entrepreneurial activity levels of a territory, first the positive influence of entrepreneurial activity on GDP per capita must be established. This is what is tested through the second hypothesis H2. With the results of the first model in Table 3 it can be seen how the entrepreneurial activity level of a territory has a 
positive and significant influence over that territory's GDP per capita. Hypothesis $\mathbf{H 2}$ is therefore confirmed by the results of the model.

--- Insert Table 3 about here ---

Along with the entrepreneurial activity level of the territory, it can be observed how the average level of formal education of a territory's population also has a direct positive influence on GDP per capita. To the contrary, a territory's unemployment rate as well as its level of rurality (measured as a proportion of population living in rural areas) is found to have a negative and significant influence on GDP per capita.

The model also shows how the considered social traits of a territory indirectly influences its GDP per capita through their impact over the entrepreneurial activity level of that territory. Specifically, it is found that the level of self-confidence of a territory's population in their entrepreneurial skills as well as the proportion of entrepreneurial role-models positively and significantly increases the entrepreneurial activity levels of that territory, consequently contributing to greater levels of GDP per capita. To the contrary, the proportion of the adult population declaring fear of entrepreneurial failure is found to negatively influence its level of entrepreneurial activity and therefore indirectly lower that territory's GDP per capita.

Summarizing the results from the first two hypotheses, it was shown how contrary to expectations set by the literature review (Verheul and Van Stel, 2007), the proportion of young adults in a territory is not a stimulus for higher GDP per capital, but rather carries no significant influence. Nevertheless, the second hypothesis linking a territory's entrepreneurial activity to GDP per capita holds true. We could therefore conjecture that rather than the proportion of young adults in general, it is the proportion of youths involved in entrepreneurial activities within a territory that is linked to that territory's greater GDP per capita. However, the results from the second model that separates youth entrepreneurial activity from that of non-youths does not support this assumption. The level of youth entrepreneurial activity of a territory is found to have no significant influence over that territory's GDP per capita. To the contrary, the greater a territory's entrepreneurial activity level amongst its non-youth population, the greater that territory's GDP per capita will be according to the significant positive result found in the model. Therefore, contrary to hypothesis $\mathbf{H 3}$, a territory's youth entrepreneurial 
activity level does not have a greater impact on GDP per capita than does the entrepreneurial activity level of non-youth.

Part of the explanation for this can be extrapolated from the results of the second model. The population density and rurality of a territory both have a significant and negative influence on entrepreneurial activity levels, but only in the case of young adults. This means that whereas the entrepreneurial activity levels of older individuals are not influenced by these geographical variables, the levels of youth entrepreneurial activity are found to be highest in lower density territories with an urban concentrated population distribution.

This is contrary to where youth entrepreneurial activity has been found to be most important. North and Smallbone (2006) found that the potential economic and social contribution of rural youths to the development of their territories can be amplified by getting them involved in entrepreneurial activity. According to Bryden and Hart (2005) entrepreneurial activity in rural areas helps to diversify the economic network and thus avoid dependence on mono-production, supplying a greater range of services, thus improving the quality of living in these areas. Likewise, entrepreneurship is a good way to generate opportunities for professional development, social and economic integration, the maintenance of the rural population and the attraction of new residents to these territories (Bryden et al., 2011; Akgün et al., 2010). Therefore, the finding that the levels of youth entrepreneurial activity are lowest in the territories where the greatest socio-economic impact can potentially be derived from this activity could explain why a territory's youth entrepreneurial activity level in Spain is not contributing to its GDP per capita.

Likewise, the results of the second model indicate that a territory's GDP per capita is strongly influenced by the indirect impact of the analyzed social traits through their influence over the entrepreneurial activity levels of non-youths in the territory. Specifically, the positive influence of a territory's entrepreneurial self-confidence and the high proportion of role models were only found to significantly influence the entrepreneurial activity levels of non-youths, and subsequently that territory's GDP per capita. This is not the case for youth entrepreneurial activity levels. 


\section{Conclusions and implications}

Youth population and young entrepreneurs have been identified as a crucial resource for territorial economic performance. A territory optimizes its economic potential when its local youth efficiently inject their human capital within the economy, either through their labor market participation or through entrepreneurial activities. Whereas research on youth and employment is readily available, knowledge of the influence and impact of youth entrepreneurial activity on economic performance has only been sparsely analyzed. Even less research is available on the relative contribution of entrepreneurial activity of younger vs. older entrepreneurs. The study presented in this paper searched to contribute to filling this gap in the literature.

Using a longitudinal database that includes economic, demographic and entrepreneurial information of 52 Spanish provinces between 2004 and 2008, a panel data model was elaborated to test whether youth entrepreneurs have a greater impact on economic performance than older entrepreneurs at the territorial level in Spain.

Based on the analyzed model, it was found that entrepreneurial activity in Spain positively impacted territorial GDP per capita over the period between 2004 and 2008. However, contrary to what was expected, the entrepreneurial activity of Spanish youth was not found to represent a dominant contributor to territorial economic performance. Older entrepreneurs in the case of Spain contributed more to increasing GDP per capita at the territorial level.

From an academic perspective, this research corroborates that Spain is not an exception in a long list of countries where entrepreneurship has been confirmed as a critical factor for economic performance. Yet, contrary to the literature (Hofer and Delaney, 2010; Liddle, 2011), the proportion of youth and their entrepreneurial activity does not contribute significantly to economic performance in Spain. This can be explained with the differences of the impact of a territory's entrepreneurial selfconfidence and role models over youth and non-youth entrepreneurial activity levels. Then, the usual academic assumption of homogeneity in the influence of these social traits across the population and territories should be revised in future studies.

With respect to policy making, the implications arising from this research are related to the need for specifically designed policy and programs that promote entrepreneurship amongst young people. Youths are not establishing their new businesses where they could have their greatest impact. Normally, a new firm's socio- 
economic impact is greatest in either a remote rural context or in a dynamic urban metropolis (OECD, 2009). Both these areas were found to have relatively less youth entrepreneurial activity in Spain.

In the case of rural areas, how the social traits of the community and specifically affect the younger segments of their population and their propensity towards a local entrepreneurial career should be taken into account. Thus, it is likely that rural youths are not identifying with the rural entrepreneurs they know, because they have been brought up to value and desire an urban lifestyle (Meccheri and Pelloni, 2006; Akgün et $a l ., 2010)$. This would mean that in order to reach greater rates of entrepreneurial activity amongst rural youths, policy must address and work to mould the value system of the community in general, and not exclusively that of young adults. Before youths can be driven to become entrepreneurs; parents, friends, educators and other key persons of influence must first believe that a local career, and one as an entrepreneur, is a profession of status and indicative of personal as well as social success.

Also, young people should be encouraged to take better advantage of the opportunities offered by metropolitan areas for creating high value added new businesses. Classical and contemporary economic thinking has consistently portrayed urban agglomerations as the preferred setting for conducting business. Wagner and Sternberg (2004) found that entrepreneurial activity in territories with high population density and high growth rates of population show higher rates of nascent entrepreneurs (Wagner and Sternberg, 2004). Similarly, according to Audretsch and Keilbach (2007) in the theory of knowledge spillover entrepreneurship, a context with more knowledge will generate more entrepreneurial opportunities; by contrast, context with less knowledge will generate fewer entrepreneurial opportunities. In the specific case of younger entrepreneurs that have less experience and greater resource deficiencies, a metropolitan context can potentially offer access to a multitude of complimentary resources to help young entrepreneurs better optimize the utilization of their human capital within their new ventures.

Otherwise, successful plans of actions that contribute towards encouraging young people to become entrepreneurs must not only offer opportunities to gain knowledge and skills. It should also engage and include youths in the socio-economic development projects of their community, and do so from an early age. If the human capital of a territory's youth is not well utilized in a society, it can easily end up 
channeled towards socially undesirable illicit and criminal activities (Walton, 2010). Precisely, Europe is currently facing a social phenomenon related with its youth which has been denominated as NEETs (young people not in employment, education or training). In the case of these youth, they have no studies or formal training not because they did not have access to the education system of these countries; but rather due to their wider social exclusion (Eurofound, 2012). According to the Eurofound, Spain is one of the European countries with the greater number of NEETs. In 2011 they were estimated to total over 1.6 million individuals; some $21 \%$ of the active population.

Finally, this research opens new lines of study. It would be interesting to include an analysis of the initiatives being promoted by young entrepreneurs in Spain. Recent reports have found that Spanish young entrepreneurs are not creating innovative firms (Vaillant et al., 2012). A comparative youth entrepreneurs study between countries with similar economic performance but different industrial and services sectors, it will show interesting nuances of this problem too.

\section{References}

Acs Z. 1996. Small Firms and Economic Growth. In, Acs Z., Carlsson B., Thurik R. (eds.), Small Business in the Modern Economy. Blackwell Publishers, Oxford.

Acs Z., Audretsch D., Braunerhjelm P., Carlsson B. 2004. The missing link: the knowledge filter and endogenous growth. Discussion paper. Center for Business and Policy Studies, Stockholm.

Acs Z., Amoros J. 2008. Entrepreneurship and competitiveness dynamics in Latin America. Small Business Economics, 31: 305-322.

Akgün A., Nijikamp P., Baycan T., Brons M. 2010. Embeddedness of entrepreneurs in rural areas: a comparative rough set data analysis. Tijdschrift voor Economische en Sociale Geografie 101(5): 538-553.

Amit R., Muller E., Cockburn I. 1995. Opportunity costs and entrepreneurial activity. Journal of Business Venturing 10: 95-106.

Audretsch D. 2009. The entrepreneurial society. Journal of Technology Transfer 34: 245-254.

Audretsch D., Falck O., Feldman M., Heblich S. 2012. Local Entrepreneurship in Context. Regional Studies 46(3): 379-389. 
Audretsch D., Keilbach M. 2007. The Theory of Knowledge Spillover. Entrepreneurship Journal of Management Studies 44(7): 1242-1253.

Audretsch D., Thurik R. 2001. Linking Entrepreneurship to Growth. Paris: OECD Directorate for Science, Technology and Industry Working Papers.

Benneworth P. 2004. In what sense 'regional development?': Entrepreneurship, underdevelopment and strong tradition in the periphery. Entrepreneurship \& Regional Development 16(6): 439-458.

Blanchflower D., Meyer B. 1994. A Longitudinal Analysis of the Young Self-Employed in Australia and the United States. Small Business Economics 6: 1-19.

Boletín Oficial del Estado (BOE) 2010. Ley 752/2010, de 4 de junio, para el desarrollo sostenible del medio rural. Ministerio de la Presidencia (Madrid: España).

Bönte W., Falck O., Heblich S. 2009. The Impact of Regional Age Structure on Entrepreneurship. Economic Geography 85(3): 269-287.

Bosma N., Levie J., Global Entrepreneurship Research Association (GERA) 2010. Global Entrepreneurship Monitor, 2009 Global report. GEM.

Bryden J., Efstratoglou S., Ferenczi T., Johnson T., Knickel K., Refsgaard K., Thomson K. 2011. Towards Sustainable Rural Regions in Europe. Routledge, New York and London.

Bryden J., Hart K. 2005. Why local economies differ: the dynamics of rural areas in Europe. The Edwin Mellen Press: Aberdeen, Scotland.

Carree M., Thurik R. 2002. The Impact of Entrepreneurship on Economic Growth. In International Handbook of Entrepreneurship Research, Acs Z., Audretsch, D. (eds.). Boston/Dordrecht: Kluwer Academic Publishers.

Chigunta F. 2002. Youth Entrepreneurship: Meeting the Key Policy Challenges. Oxford, UK; Oxford University Press.

Corduras A., Hernández R., Sánchez M., Díaz J., Vaillant Y., Lafuente E. 2012. Informe GEM España 2011. Trujillo-Cáceres: Fundación Xavier de Salas-GEM España.

Davidsson P. 1995. Culture, structure and regional levels of entrepreneurship. Entrepreneurship and Regional Development 7: 41-62.

De Jorge Moreno J., Laborda Castillo L., De Zuani Masere E. (2007). Influence of entrepreneur type, region and sector effects on business self-confidence: Empirical evidence from Argentine firms. Entrepreneurship \& Regional Development 19(1): $25-48$. 
Driga O., Lafuente E., Vaillant Y. 2009. Reasons behind the relatively lower entrepreneurial activity levels of rural women: looking into rural Spain. Sociologia Ruralis 49(1): 70-96.

Headey D., Hodge A. 2009. The Effect of Population Growth on Economic Growth: A Meta-Regression Analysis of the Macroeconomic Literature. Population and Development Review 35(2): 221-248.

European Commission 2012. Focus on: Youth Employment. Youth in Action programme. Available at http://ec.europa.eu/youth/pub/publications_en.htm. Last Accessed: May 12, 2012.

European Commission 2009. Youth - Investing and Empowering. SEC(2009) 549 final. Brussels: European Commission.

European Commission 2004. Action Plan: The European Agenda for Entrepreneurship. Communication from the Commission to the Council, the European Parliament, the European Economic and Social Committee and the Committee of the Regions, $\operatorname{COM}(04) 70$.

Eurofound: European Foundation for the Improvement of Living and Working Conditions 2012. NEETs Young people not in employment, education or training: Characteristics, costs and policy responses in Europe. Luxembourg: Publications Office of the European Union.

Eurostat 2009. Youth in Europe, a statistical portrait. Luxembourg: Publications Office of the European Union.

Fougère M., Mérette M. 1999. Population Ageing and Economic Growth in Seven OECD Countries. Economic Studies and Policy Analysis Division Department of Finance, Canada.

Freytag A., Thurik R. 2007. Entrepreneurship and its determinants in a cross-country setting. Journal of Evolutionary Economics 17: 117-131.

Fritsch M. 2008. How does new business formation affect regional development? Introduction to the special issue. Small Business Economics 30: 1-14.

Fritsch M., Mueller P. 2008. The effect of new business formation on regional development over time: the case of Germany. Small Business Economics 30: 15-29.

Fritsch M., Schindele Y. 2011. The Contribution of New Businesses to Regional Employment-An Empirical Analysis. Economic Geography 87(2): 153-180. 
Futucami K., Nakajima T. 2001. Population Aging and Economic Growth. Journal of Macroeconomics 23(1): 31-44.

Gibson D. 2004. Role models in career development: New directions for theory and research. Journal of Vocational Behavior 65(1): 134-156.

Göel A., Zhang L., Arora B. 2006. Attitudes of the youth towards entrepreneurs and entrepreneurship: A cross-cultural comparison of India and China. Journal of Asia Entrepreneurship and Sustainability 3(1): 1-35.

Grilo I., Thurik R. 2006. Entrepreneurship in the old and the new Europe. In Entrepreneurship, Growth and Innovation, Santarelli E. (ed.), Berlin: Springer Verlag.

Headey D., Hodge A. 2009. The Effect of Population Growth on Economic Growth: A Meta-Regression Analysis of the Macroeconomic Literature. Population and Development Review 35(2): 221-248

Hofer A., Delaney, A. 2010. Shooting for the Moon: Good Practices in Local Youth Entrepreneurship Support. LEED Working Papers. Paris: OECD Publishing.

Honjo Y. 2004. Growth of new start-up firms: evidence from the Japanese manufacturing industry. Applied Economics 11(1): 21-32.

ILO (International Labor Organization) 2010. Global employment trends for youth. Geneve: ILO.

Karlsson C., Friis C., Paulsson T. 2004. Relating entrepreneurship to economic growth. CESIS/JIBS.

Katz J. 1994. Modelling entrepreneurial career progressions: concepts and considerations. Entrepreneurship Theory and Practice 19: 23-36.

Krueger N., Brazeal D. 1994. Entrepreneurial potential and potential entrepreneurs. Entrepreneurship Theory and Practice 18(3): 91-104.

Lafuente E., Vaillant Y., Rialp J. 2007. Regional Differences in the Influence of Role Models: Comparing the Entrepreneurial Process of Rural Catalonia. Regional Studies 44: 779-795.

Landier A. 2004. Entrepreneurship and the stigma of failure. Paper presented at the MIT finance, development and macro workshops, U.S.

Levesque M., Minniti M. 2006. The effect of aging on entrepreneurial behavior. Journal of Business Venturing 21(2): 177-194. 
Liddle B. 2011. Demographic influences on economic resiliency: revisiting the developing country growth collapse of the 1970s and 1980s. Journal of International Development 23: 476-492.

Lucas W., Cooper S., Ward T., Cave F. 2009. Industry placement, authentic experience and the development of venturing and technology self-efficacy. Technovation 29(11): 738-752.

Lyngdoh B. 2005. Skills for Work in the Future: A Youth Perspective. Quarterly Review of Comparative Education 35(3): 311-316.

Mcgee J., Peterson M., Mueller M., Sequeira J. 2009. Self-efficacy: refining the measure. Entrepreneurship Theory and Practice 33(4): 965-988.

Malecki E. 1993. Entrepreneurship in Regional and Local Development International. Regional Science Review 16: 119-153.

Meccheri N., Pelloni G. 2006. Rural entrepreneurs and institutional assistance: an empirical study from mountainous Italy. Entrepreneurship and Regional Development 18 (5): 371-392.

Muilu T., Rusanen J. 2003. Rural young people in regional development, the case of Finland in 1970-2000. Journal of Rural Studies 19: 295-307.

Naudé W., Gries T., Wood E., Meintjies A. 2008. Regional determinants of entrepreneurial start-ups in a developing country. Entrepreneurship \& Regional Development 20 (2): 111-124.

North D.J., Smallbone D. 2006. Developing entrepreneurship and enterprise in Europe's peripheral rural areas: some issues facing policy-makers. European Planning Studies 14 (1): 41-60.

OECD 1998. Fostering Entrepreneurship. Paris: OCDE.

OECD 2001. Putting the Young in Business, policy challenges for youth entrepreneurship. LEED Notebook No. 29. Paris: OCDE.

OECD 2003. Entrepreneurship and local economic development: Programme and policy recommendations. Paris and Washington, D.C.: OECD.

OECD 2009. OECD Rural Policy Reviews, Spain. Paris: OCDE.

OECD 2010. OECD Rural Policy Reviews, Québec (Canada). Organisation for Economic Co-operation and Development, Paris: OCDE.

OECD 2012. Territorial Review of Smaland-Blekinge. Paris: OCDE. 
Reynolds P., Bosma N., Auio E., Hunt S., de Bono N., Servais I., López-Gárcia P., Chin N. 2005. Global Entrepreneurship Monitor: Data Collection Design and Implementation 1998-2003. Small Business Economics 24: 205-231.

Rojas G., Siga L. 2009. On the nature of micro-entrepreneurship: evidence from Argentina. Applied Economics 41(21): 2667-2680.

Schiller B., Crewson P. 1997. Entrepreneurial origins: A longitudinal inquiry. Economic Inquiry 35(3): 523-529.

Schroeder C., Heinert L., Bauer L., Markley D., Dabson K. 2010. Energizing young entrepreneurs in rural communities. Center for Rural Entrepreneurship RUPRI and Hometown Competitiveness. Nebraska: Heartland Centre Publications. Online: http://www.energizingentrepreneurs.org/content/cr_7/2_000240.pdf

Thomas K. 2009. The impact of education histories on the decision to become selfemployed: a study of young, aspiring, minority business owners. Small Business Economics 33(4): 455-466.

Thurik R.. Wennekers S. 2001. A Note on Entrepreneurship, Small Business and Economic Growth. Rotterdam: Erasmus Research Institute of Management Report Series.

United Nations 2005. Entrepreneurship and Economic development: the empretec showcase. Geneva: United Nations Conference on Trade and Development (UNCTAD/WEB/ITE/TEB/2004/3)

Vaillant Y., Guallarte C., Lafuente E., Gómez E., Mancilla C., Figuls M., Bayon M. 2012. Informe Ejecutiu Catalunya 2011. GEM-Catalunya, IERMB:Barcelona.

Vaillant Y., Lafuente E. 2007. Do different institutional frameworks condition the influence of local fear of failure and entrepreneurial examples over entrepreneurial activity? Entrepreneurship and Regional Development 19(4): 313-337.

Van Groezen B., Meijdam L. 2004. Growing old and staying young: population policy in an ageing closed economy. Utrecht School of Economics, Tjalling C. Koopmans Research Institute. Discussion Paper series 04-28.

Van Stel A., Carree M., Thurik R. 2005. The effect of entrepreneurial activity on national economic growth. Small Business Economics 24: 311-321.

Verheul I., Van Stel A. 2007. Entrepreneurial Diversity and Economic Growth. ERIM Report Series reference number ERS-2007-070-ORG. http://hdl.handle.net/1765/10619 
Wagner J. 2002. The Role of the Regional Milieu for the Decision to Start a New Firm: Empirical Evidence for Germany. Discussion Paper No. 494.

Wagner J. 2004. Are young and small firms hothouses for nascent entrepreneurs? Evidence from German micro data. Applied Economics Quarterly 50: 379-391.

Wagner J., Sternberg R. 2004. Start-up activities, individual characteristics, and the regional milieu: Lessons for entrepreneurship support policies from German micro data. Annals of Regional Sciences 38: 219-240.

Wagner J. 2007. What a Difference a Y makes-Female and Male Nascent Entrepreneurs in Germany. Small Business Economics 28(1): 1-21.

Walstad W., Kourilsky M. 1998. Entrepreneurial attitudes and knowledge of black youth. Entrepreneurship Theory and Practice 23(2): 5-18.

Walton O. 2010. Youth, armed violence and job creation programmes. Norwegian Peace building Centre (NOREF) on youth and armed violence, Norway.

Wennekers S., Thurik R. 1999. Linking entrepreneurship and economic growth. Small Business Economics 13: 27-55.

Wennekers S., Van Wennekers A., Thurik R., Reynolds P. 2005. Nascent Entrepreneurship and the Level of Economic Development. Small Business Economics 24(3): 293-309.

Wennkers S., Van Stel A., Carree M. 2010. The relationship between entrepreneurship and economic development: is it U-shaped? EIM Research Reports, SCALESinitiative, The Netherlands.

Werner Sinn H. 1999. The Crisis of Germany's Pension Insurance System and How It Can Be Resolved. NBER Working Paper No. 7304.

White S., Kenyon P. 2000. Enterprise-Based Youth Employment Policies, Strategies and Programmes. Geneva: Drat Report to ILO.

Wooldridge J.M. 2002. Econometric Analysis of Cross Section and Panel Data. Cambridge, Massachusetts: The MIT Press.

Wyrwich M. 2012. Regional Entrepreneurial Heritage in a Socialist and a Postsocialist Economy. Economic Geography 88(4): 423-445.

Xavier S.R., Kelley D., Kew J., Herrington M., Vorderwülbecke A. 2012. Global Entrepreneurship Monitor 2012 Global Report. Online: http://www.gemconsortium.org/ Access: 14/02/13. 
Xheneti M. 2006. Youth entrepreneurship in south east Europe: some policy recommendations. In: Promoting Entrepreneurship in South East Europe, policies and tools. Edited by Jonathan Potter and Alessandra Proto. Paris: OECD.

\section{Biographical note:}

Esteban Lafuente is professor in the Department of Management at the Universitat Politècnica de Catalunya (UPC, Barcelona Tech). He also served as Main Researcher in the Catalan entrepreneurship observatory, Global entrepreneurship Monitor (GEMCatalunya) between 2009 and 2013. His research interests focuses on economic and managerial aspects of organisations, and entrepreneurship.

Corresponding author:

Esteban Lafuente

Department of Management, Universitat Politècnica de Catalunya (Barcelona Tech) EPSEB, Av. Gregorio Marañón, 44-50, 08028 Barcelona, Spain

Email: esteban.lafuente@upc.edu

Eduardo Gómez-Araujo is presently a professor at the School of Business, Universidad del Norte (Colombia). He also acts as Main Researcher in the Colombian Global entrepreneurship Monitor (GEM-Catalunya) since 2014. He earned his PhD from the Autonomous Universsity of Barcelona (UAB), and his research focuses on the study of the entrepreneurial activity from an individual and territorial perspective. 


\section{List of Figures}

Figure 1. Provinces of Spain

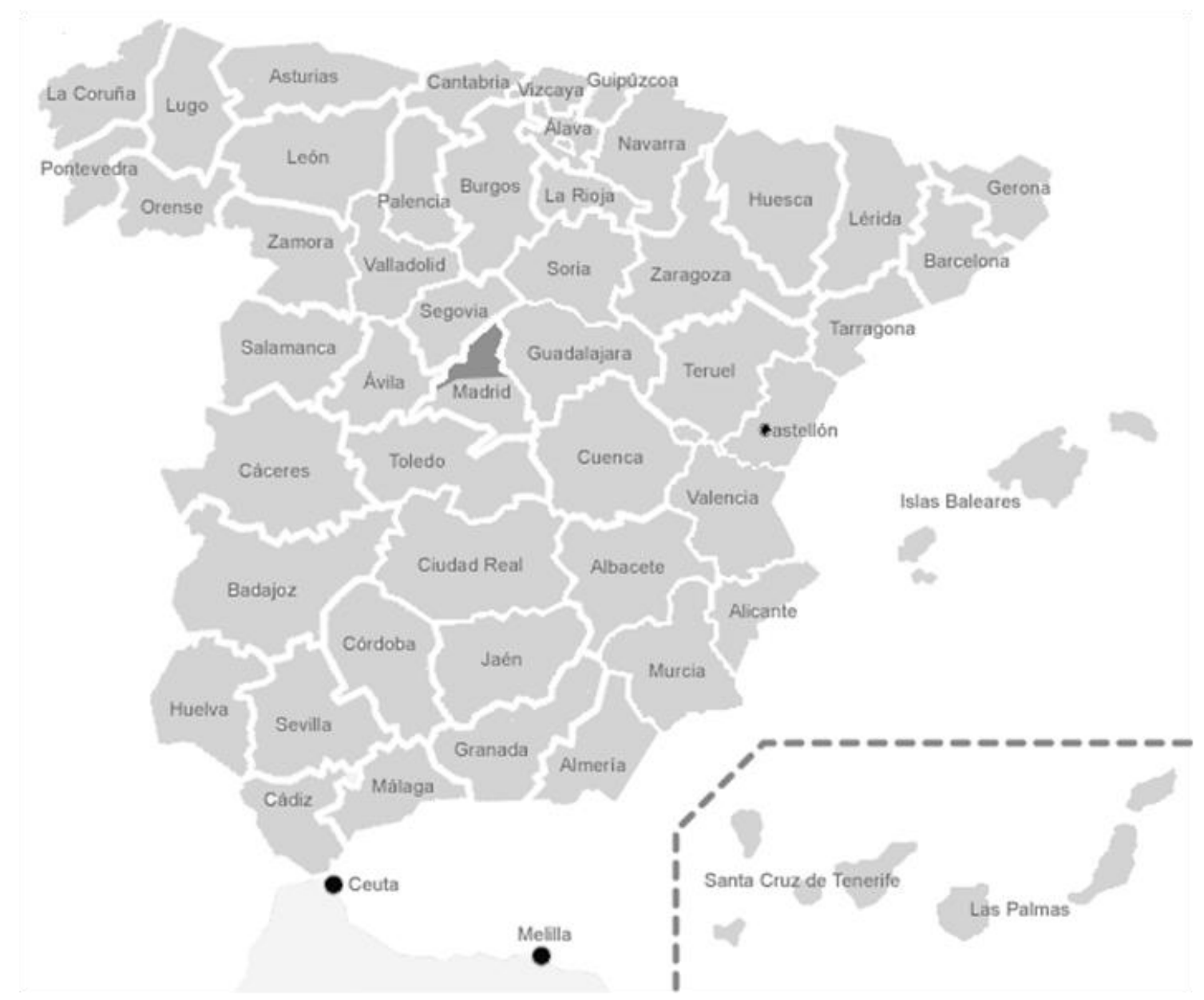




\section{List of Tables}

Table 1. Descriptive statistics: Entrepreneurial activity and GDP per capita

\begin{tabular}{|c|c|c|c|c|c|}
\hline Year & $\begin{array}{c}\text { Entrepreneurial } \\
\text { activity }\end{array}$ & $\begin{array}{c}\text { Entrepreneurial } \\
\text { activity (Youth) }\end{array}$ & $\begin{array}{c}\text { Entrepreneurial } \\
\text { activity } \\
\text { (Non-youth) }\end{array}$ & $\begin{array}{c}\text { GDP per } \\
\text { capita } \\
\text { (in euro) }\end{array}$ & Obs. \\
\hline 2004 & $\begin{array}{c}0.0137 \\
(0.0132)\end{array}$ & $\begin{array}{c}0.0155 \\
(0.0240)\end{array}$ & $\begin{array}{c}0.0132 \\
(0.0127)\end{array}$ & $\begin{array}{c}21,585.33 \\
(4,389.881)\end{array}$ & 52 \\
\hline 2005 & 0.0207 & 0.0189 & 0.0224 & $22,096.73$ & 52 \\
& $(0.0171)$ & $(0.0222)$ & $(0.0167)$ & $(4,409.543)$ & \\
\hline 2006 & 0.0309 & 0.0249 & 0.0322 & $22,996.39$ & 52 \\
\hline 2007 & $(0.0165)$ & $(0.0194)$ & $(0.0196)$ & $(4,612.762)$ & 52 \\
& 0.0283 & 0.0293 & 0.0279 & $23,297.91$ & 52 \\
\hline 2008 & $(0.0109)$ & $(0.0242)$ & $(0.0114)$ & $(4,647.288)$ & 52 \\
& $(0.0106)$ & $(0.0178)$ & $(0.0119)$ & $(4,714.002)$ & 52 \\
\hline \multirow{2}{*}{ Total } & 0.0237 & 0.0225 & 0.0241 & $22,672.52$ & 260 \\
& $(0.0150)$ & $(0.0220)$ & $(0.0159)$ & $(4,576.836)$ & \\
\hline
\end{tabular}

Standard deviation is presented in brackets.

Table 2. Descriptive statistics: Demographic variables and social traits

\begin{tabular}{|l|c|c|c|}
\hline & Mean & Standard deviation & Obs. \\
\hline Population density & 285.8664 & 842.6254 & 260 \\
\hline Unemployment rate & 0.0980 & 0.0397 & 258 \\
\hline $\begin{array}{l}\text { Education (Proportion of people with } \\
\text { university studies) }\end{array}$ & 0.2001 & 0.0527 & 258 \\
\hline $\begin{array}{l}\text { Rurality (Proportion of population living } \\
\text { in rural areas) }\end{array}$ & 0.3994 & 0.2796 & 260 \\
\hline Proportion of young people & 0.2002 & 0.0235 & 260 \\
\hline Skills & 0.4493 & 0.0628 & 258 \\
\hline Role models & 0.3247 & 0.0637 & 257 \\
\hline Fear Failure & 0.4924 & 0.0748 & 257 \\
\hline
\end{tabular}

The number of observations varies due to the presence of some missing values. 
Table 3: Three-stage least squares: Entrepreneurial activity and economic performance

\begin{tabular}{|c|c|c|c|c|c|}
\hline & \multicolumn{2}{|c|}{ Model (1) } & \multicolumn{3}{|c|}{ Model (2) } \\
\hline & $\begin{array}{l}\text { GDP per } \\
\text { capita }\end{array}$ & $\begin{array}{l}\text { Entrepreneurial } \\
\text { activities }\end{array}$ & $\begin{array}{l}\text { GDP per } \\
\text { capita }\end{array}$ & $\begin{array}{l}\text { Young e- } \\
\text { ship }\end{array}$ & Old e-ship \\
\hline $\begin{array}{l}\text { Entrepreneurial } \\
\text { activity }\end{array}$ & $\begin{array}{c}3.8925 * * * \\
(1.4885)\end{array}$ & & & & \\
\hline $\begin{array}{l}\text { Entrepreneurial } \\
\text { activity (Youth) }\end{array}$ & & & $\begin{array}{l}-2.3245 \\
(3.6633)\end{array}$ & & \\
\hline $\begin{array}{l}\text { Entrepreneurial } \\
\text { activity (Old) }\end{array}$ & & & $\begin{array}{l}4.5478 * * \\
(2.2235)\end{array}$ & & \\
\hline $\begin{array}{l}\text { Population } \\
\text { density }\end{array}$ & $\begin{array}{c}0.0084 \\
(0.0120) \\
\end{array}$ & $\begin{array}{l}-0.0014 \\
(0.0017)\end{array}$ & $\begin{array}{c}0.0010 \\
(0.0206)\end{array}$ & $\begin{array}{l}-0.0050^{*} \\
(0.0027)\end{array}$ & $\begin{array}{l}-0.0013 \\
(0.0018)\end{array}$ \\
\hline Unemployment & $\begin{array}{c}-1.6841 * * * \\
(0.3022) \\
\end{array}$ & $\begin{array}{c}-0.0163 \\
(0.0418) \\
\end{array}$ & $\begin{array}{c}-1.4538 * * * \\
(0.5270) \\
\end{array}$ & $\begin{array}{c}0.0909 \\
(0.0680) \\
\end{array}$ & $\begin{array}{l}-0.0379 \\
(0.0450) \\
\end{array}$ \\
\hline Education & $\begin{array}{c}1.3924 * * * \\
(0.2124)\end{array}$ & $\begin{array}{r}-0.0293 \\
(0.0292) \\
\end{array}$ & $\begin{array}{c}1.2694 * * * \\
(0.2647)\end{array}$ & $\begin{array}{l}-0.0439 \\
(0.0477) \\
\end{array}$ & $\begin{array}{l}-0.0228 \\
(0.0316)\end{array}$ \\
\hline Rurality & $\begin{array}{c}-0.1206^{* * *} \\
(0.0519)\end{array}$ & $\begin{array}{l}-0.0024 \\
(0.0073) \\
\end{array}$ & $\begin{array}{c}-0.1617^{*} \\
(0.0961) \\
\end{array}$ & $\begin{array}{c}-0.0224^{*} \\
(0.0118) \\
\end{array}$ & $\begin{array}{l}-0.0022 \\
(0.0078) \\
\end{array}$ \\
\hline $\begin{array}{l}\text { Proportion of } \\
\text { young adults }\end{array}$ & $\begin{array}{c}0.2701 \\
(0.3551) \\
\end{array}$ & $\begin{array}{c}0.0172 \\
(0.0497) \\
\end{array}$ & $\begin{array}{r}-0.0525 \\
(0.4864) \\
\end{array}$ & $\begin{array}{l}-0.0502 \\
(0.0815) \\
\end{array}$ & $\begin{array}{c}0.0671 \\
(0.0540) \\
\end{array}$ \\
\hline Skills & & $\begin{array}{c}0.0531 * * * \\
(0.0166)\end{array}$ & & $\begin{array}{c}0.0043 \\
(0.0282) \\
\end{array}$ & $\begin{array}{c}0.0556 * * * \\
(0.0183)\end{array}$ \\
\hline Role models & & $\begin{array}{c}0.0491 * * * \\
(0.0161)\end{array}$ & & $\begin{array}{c}0.0208 \\
(0.0285) \\
\end{array}$ & $\begin{array}{c}0.0542 * * * \\
(0.0180)\end{array}$ \\
\hline Fear Failure & & $\begin{array}{c}-0.0426 * * * \\
(0.0153)\end{array}$ & & $\begin{array}{c}-0.0460^{*} \\
(0.0262)\end{array}$ & $\begin{array}{c}-0.0357 * * * \\
(0.0173)\end{array}$ \\
\hline Time dummies & Yes & Yes & Yes & Yes & Yes \\
\hline $\begin{array}{l}\text { Territorial } \\
\text { dummies }\end{array}$ & Yes & Yes & Yes & Yes & Yes \\
\hline Intercept & $\begin{array}{c}9.8388 * * * \\
(0.1121)\end{array}$ & $\begin{array}{r}0.0116 \\
(0.0191) \\
\end{array}$ & $\begin{array}{c}9.9621 * * * \\
(0.1966) \\
\end{array}$ & $\begin{array}{c}0.0705^{* *} * \\
(0.0331)\end{array}$ & $\begin{array}{l}-0.0007 \\
(0.0219)\end{array}$ \\
\hline R squared & 0.7967 & 0.3075 & 0.7426 & 0.1455 & 0.2852 \\
\hline Chi2 value & $1050.70 * * *$ & $111.76^{* * *}$ & $827.33 * * *$ & $42.56 * * *$ & $99.74 * * *$ \\
\hline $\begin{array}{l}\text { Root mean } \\
\text { square error }\end{array}$ & 0.0893 & 0.0125 & 0.1010 & 0.0203 & 0.0135 \\
\hline Observations & 250 & 250 & 250 & 250 & 250 \\
\hline
\end{tabular}

$*, * *, * * *$ indicates significance at the $10 \%, 5 \%$, and $1 \%$, respectively. 